Article

\title{
Climate Change Scepticism at Universities: A Global Study
}

\author{
Walter Leal Filho ${ }^{1,2} \mathbb{C}^{\text {, Mark Mifsud }}{ }^{3, *}$, Petra Molthan-Hill ${ }^{4}$, Gustavo J. Nagy ${ }^{5}$, \\ Lucas Veiga Ávila ${ }^{6, *}$ and Amanda Lange Salvia 2 (1) \\ 1 School of Science and the Environment, Manchester Metropolitan University, Manchester M1 5GD, UK; \\ walter.leal2@haw-hamburg.de \\ 2 European School of Sustainability Science and Research, Hamburg University of Applied Sciences, \\ Ulmenliet 20, D-21033 Hamburg, Germany; amandasalvia@gmail.com \\ 3 Centre for Environmental and Education Research, University of Malta, MSD 2080 Msida, Malta \\ 4 Nottingham Business School, Nottingham Trent University, Nottingham NG1 4FQ, UK; \\ petra.molthan-hill@ntu.ac.uk \\ 5 Facultad de Ciencias, Universidad de la República, Montevideo 11400, Uruguay; gnagy@fcien.edu.uy \\ 6 Department of Postgraduate Studies in Administration, Federal University of Santa Maria-UFSM, \\ Ernesto Barros, 1345, Santo Antônio, Cachoeira do Sul ZIP 96506-322, Brazil \\ * Correspondence: mark.c.mifsud@um.edu.mt (M.M.); admlucasveiga@gmail.com (L.V.Á.)
}

Received: 13 May 2019; Accepted: 19 May 2019; Published: 25 May 2019

\begin{abstract}
Scepticism about climate change is still a popular trend, despite the existence of scientific evidence that this phenomenon is taking place, and that it is influencing the lives of millions of people around the world. The aim of this paper is to assess the extent to which existing scepticism at the university level is found. The methodology consists of a survey undertaken on a sample of universities around the world, in the context of which attitudes and perceptions about climate change are identified. A total of 237 questionnaires were received from 51 countries around the world. The analysis consists basically of descriptive statistics and an investigation regarding trends on scepticism and the geographical location of the universities. The study concludes by outlining some of the presently seen scepticisms and suggests some ways to address them via curricular innovation and initiatives engaging students.
\end{abstract}

Keywords: climate change; universities; scepticism; education; change; engagement; online; global study

\section{Introduction}

Universities play a significant role in responding to climate change by creating knowledge and integrating the handling of climate issues in educational and research programs, as well as direct and indirect operational activities. An evaluation of the green development plans of a sample of 178 universities undertaken in 2011 showed that the climate change criteria is one of the most current parameters taken into account by many of them [1].

The role of universities in acting on climate change cannot be underestimated. Despite a continually increasing level of attention to the problem, the applied efforts are not robust and similar across the globe. Therefore, the current state urges further and more intensive cooperation on the problem among world universities.

The patchy response to climate change across universities worldwide raises the question whether climate scepticism at universities is prevalent and leads to universities taking limited action. Only a few universities seem to integrate climate change into their curricula; this might point towards the 
actors in the university being sceptical about climate change in general and/or its seriousness and/or its impact. When it comes to climate change research, the situation is comparatively better: universities have been researching on climate action both globally and locally and covering different aspects of climate change impacts [2,3]. Still, there are certainly more paths to be explored in this area as well.

The importance of communication on climate change has already been established, and much research on it exists (e.g., [4,5]), but there is a comparative lack of research on climate change scepticism at universities. To meet this research need, this paper aimed at providing an international analysis of the extent to which climate scepticism is seen and perceived at universities.

The following sections present experiences from different countries and universities worldwide when it comes to action against climate change and modalities of scepticism about climate change, respectively. The second section presents the design of the survey undertaken, followed by the presentation and discussion of its results. The purpose of the study is mainly to clarify the current spread of scepticism to climate change, and to map the engagement of universities on this topic.

\subsection{Climate Action at Universities}

Undoubtedly, significant efforts to address climate change at universities are the incorporation of the problem into educational programs and research. Universities modify academic curriculum, establish research centres, and support research teams. Another common action is addressing climate change through campus greening.

Table 1 presents a summary of different experiences in climate action in universities from varied realities. In addition to local efforts and development of programs and plans focused on climate change, it is clear the importance of regional or international networks among universities, which can contribute to sharing experiences and summing efforts.

Table 1. Climate action in different universities worldwide.

\begin{tabular}{|c|c|}
\hline Country & Experience \\
\hline China & $\begin{array}{l}\text { Shenyang University, aiming at improved environmental performance, enhanced public awareness, and cost reduction } \\
\text { on campus maintenance, has undertaken a series of efforts including water recycling, the application of ground source } \\
\text { heat pump, source separation for solid wastes, green education, and enhanced research activities on environmental } \\
\text { protection [6]. }\end{array}$ \\
\hline USA & $\begin{array}{l}\text { The American College offers one of the examples of cooperation among universities on matters related to climate } \\
\text { change and University Presidents' Climate Commitment (ACUPCC), launched in } 2006 \text { as a collective effort by higher } \\
\text { education institutions (HEI) to pursue climate neutrality in campus operations and integrate climate issues into their } \\
\text { education, research, and community engagement activities [7]. } \\
\text { In 2015, } 318 \text { colleges and universities (e.g., Harvard University, Massachusetts Institute of Technology, Yale University) } \\
\text { joined the American Campuses Act on Climate Pledge launched by the President Obama Administration. By signing } \\
\text { the pledge, universities demonstrated their support for robust International Climate Action and accelerated the } \\
\text { transition to low-carbon energy while enhancing sustainable and resilient practices across their campus [8]. } \\
\text { Investment in competitions and campaigns aimed at the promotion of climate change action [9]. As an example, the } \\
\text { Campus Conservation Nationals [10] is the most significant short-term electricity reduction competition in the world, } \\
\text { with more than } 130 \text { participating universities and colleges in 2015. } \\
\text { The Cornell University has launched the program called Cornell Climate Change Program Work Team (PWT) which } \\
\text { provides a mechanism through which faculty and extension educators connect with stakeholders to identify the needs } \\
\text { surrounding climate change impacts and opportunities in New York State, create educational materials, and design } \\
\text { learning experiences that address these needs. The Cornell Institute for Climate Smart Solutions (CICSS) is focused on } \\
\text { supporting farmers of New York and beyond with decision tools for strategic adaptation to climate change [11]. }\end{array}$ \\
\hline Canada & $\begin{array}{l}\text { The College Presidents' Climate Change Statement of Action for Canada [12] is a Canadian experience which focuses } \\
\text { on both the responsibility of universities to reduce emissions and opportunities to accelerate larger solutions beyond } \\
\text { campuses [7]. }\end{array}$ \\
\hline England & $\begin{array}{l}\text { The University of Winchester introduced a Five-Year Strategy 2016-2021 on Climate Change Education. The document } \\
\text { includes objectives, strategic priorities and ways of their realisation. The University identified four strategic priority } \\
\text { areas: Embedded Education, Research, Shared Vision, and Strong Partnerships. It strives to make climate change } \\
\text { education available, accessible and relevant for all undergraduates, whatever their chosen subject; to establish a } \\
\text { Research Centre for Climate Change Education and Communications and to introduce a fully funded PhD studentship } \\
\text { in the subject [13]. }\end{array}$ \\
\hline
\end{tabular}


Table 1. Cont.

\begin{tabular}{ll}
\hline Country & \multicolumn{1}{c}{ Experience } \\
\hline Scotland & $\begin{array}{l}\text { Universities and Colleges Climate Commitment for Scotland (UCCCfS) creates a structure for universities and colleges } \\
\text { to show the reduction of carbon emissions and commitment to tackling climate change. Signatories produce and } \\
\text { publish a 5-year Climate Change Action Plan (CCAP) which will be incorporated into established improvement } \\
\text { processes, with the aim to achieve a significant reduction in emissions [14]. }\end{array}$ \\
\hline & The Research and Transfer Centre "Sustainable Development and Climate Change Management" at the Hamburg \\
University of Applied Sciences in Germany, conducts multi-disciplinary research and runs various training events on \\
climate change adaptation. It also runs the International Climate Change Information Programme, a leading provider \\
of education and training on climate change, with a variety of events being organised around the world [15].
\end{tabular}

Considering the universities' global cooperation regarding climate change, it is also worth to mention the Worldwide Universities Network (WUN), a leading global higher education and research network made up of 22 universities, from 12 countries on six continents and engaging over 2000 researchers and students. One of the studies performed focuses on the network 'Responding to Climate Change'. The project is designed to bring together academics and practitioners seeking new ways to address concerns about climate change [18].

\subsection{Scepticism about Climate Change}

Despite mounting evidence that climate change is happening [19] and causing many problems which vary from environmental changes [20] to crime rates [21] and armed conflicts [22], only a certain percentage of people in individual nations seems to be concerned about climate change and really taking actions towards that [23-25]. Indeed, recent years seem to have seen an increase in climate change scepticism [26,27]. Herein the focus of this section is on the modalities of climate change scepticisms.

Being concerned or sceptic seems to be firmly determined by individuals' environmental and political values rather than by education or knowledge [25]. Religiosity and internal locus of control have also been linked to concerns of global warming [28-31]. Generally, the attitude of doubt and uncertainty about anthropogenic climate change is considered as climate change scepticism.

Climate change scepticism refers to (i) a family of arguments and individuals that are undecided, doubt or dispute ("uncertain group") or reject the mainstream view of the climate issue [32]; (ii) doubts and uncertainty about the evidence-based scientific/physical aspects of climate change ("epistemic scepticism" [33]); (iii) belief that climate change is not occurring or that human activities are not a significant contributor [34]; (iv) a questioning of the consensus that the climate is changing as a consequence of human actions; (v) the belief that policy interventions can limit the changes [35] or "social/behavioural" or "response scepticism" [33,34,36]; and (vi) denial of climate change in the being less frequent than the perception of its exaggeration [25].

Epistemic scepticism disclaims the basic tenets of climate science as assembled through bodies such as the Intergovernmental Panel on Climate Change (IPCC) and represented by the broad tenor of the academic literature [33]. Treating the process and response issues as areas of legal disputation would help to convince the uncertain sceptics rather than dismissive of mainstream climate science [32].

In the group with 'no-concern', five correlated beliefs can be distinguished: Scepticism, avoidance, denial, fatalism and pessimism [37]. Few deny climate change in general but a high proportion question or doubt that this is caused by human activities [33,34,38]. These so-called "attribution sceptics" [33] are less likely to be engaged in any behaviour to address climate change; therefore, if this group were dominant at universities, no action would be taken. So-called "impact sceptics" [32,33] might also 
question the severity of climate change or/and its impact. Again, this would have consequences if they would dominate the decision taken at university level whether to address climate change in operations, education and research.

Furthermore, a firm belief in scientific solutions has been aligned with climate scepticism, in the sense that this group believes that solutions to all climate-related problems can be provided and that humans do not need to worry about climate change. The latter would still favour in a university context to embed these solutions into operations and teaching and to strive in research to solve more climate change related problems.

Several studies about climate sceptics have concentrated on one single poll. A recent study [31], for example, claimed that the concern about climate change is widespread over developing and developed nations alike. However, this study was based on data from 2005 to 2009. In their longitudinal analysis, utilising the results from studies published between 1980 and 2014, Capstick et al. [27] pointed out that climate change scepticism grows in the latter 2000s in some developed countries. A review performed by Björnberg et al. [39] based on articles found in the databases Web of Science, Scopus and Philosopher's Index, showed that denial by far is most studied concerning climate change, with a focus on Anglo-American countries, where this form of denial is most common.

These issues have a central relevance to this study since they help to understand the variety of views and the diversity of scepticisms seen, which influence a decision of universities to engage in climate change topics.

\section{Methods}

Methodologically, the questionnaire was developed in order to contain statements which would show what ideally universities should do as climate action and what they are really putting into practice. The literature review presented in the previous section and discussions with the Research Team of the Inter-University Sustainable Development Research Program (IUSDRP) [40] contributed to the first draft of the survey.

The statements were reviewed by the authors to reduce redundancy and similar items to ensure that all relevant issues were considered. The questionnaire was pre-tested by a panel of 10 experts in the areas of sustainability at different universities. The final version of the survey was composed of 14 statements (presented as closed questions) structured to gather information about some sociodemographic characteristics of the interviewees, including their role in the university and their perceptions about climate change. A five-point Likert Scale was used: Strongly disagree, Disagree, Do not know, Agree, Strongly agree.

Further statements probed the level of engagement of the participant and the university with climate change, including whether a university should have a climate change policy, whether a university should contribute in its operation to achieve the carbon reduction targets set by the government, and whether a university should contribute in its operation to achieve the adaptation strategies to climate change set by the government.

The last set of statements probed the curricula of universities and the possible embedding of climate change science and issues within various courses. These questions focused on whether a university should educate its students about the causes and the impacts of climate change in all disciplines and the extent to which a university should encourage its students to search for solutions with regards to problems caused by climate change. The full questionnaire can be seen in Appendix A.

The online survey was conducted from 23 June to 6 August 2017 using Survey Monkey (https: //www.surveymonkey.com/). In all, 1200 invitations were sent by email (in English), with access to the online instrument. The survey was disseminated via email (with calls made over a period of 7 weeks) to the following groups:

(a) Rectors and office managers of universities participant in the Green Sustainability Metrics 2018;

(b) Authors with more than four publications on the subject "sustainability at universities" in the Web of Science between 2009 and 2018; 
(c) Participants of the World Symposium on Sustainable Development at Universities, held in September 2016 at the Massachusetts Institute of Technology (USA) and that takes place regularly in different regions of the world bringing together the main researchers, managers and community interested in the subject;

(d) Representatives of Universities (Rector, sustainability office manager, researcher/teacher) participating in the Inter-University Program for Sustainable Development Research (IUSDRP);

(e) Representatives of the Universities (rector, sustainability office manager, researcher/professor) participating in Alliance Copernicus (Transformation of the sustainability of science systems);

(f) Rectors and Managers of the Sustainability Office of the Universities participating in the Association, for the Advancement of Sustainability in Higher Education (AACHE).

A total of 237 questionnaires were received from 51 countries around the world. Most respondents are from the United Kingdom $(n=52)$, the United States $(n=33)$, Brazil $(n=23)$, Portugal $(n=12)$ and Australia $(n=10)$. All responses were divided into six separate groups according to the region where the university is located. The most represented region was Europe with $43 \%$ of the replies, followed by South America (21\%), North America (16\%), Africa (10\%), Asia (5\%) and Oceania with $5 \%$ of all the replies. Figure 1 shows the countries participating in the study.

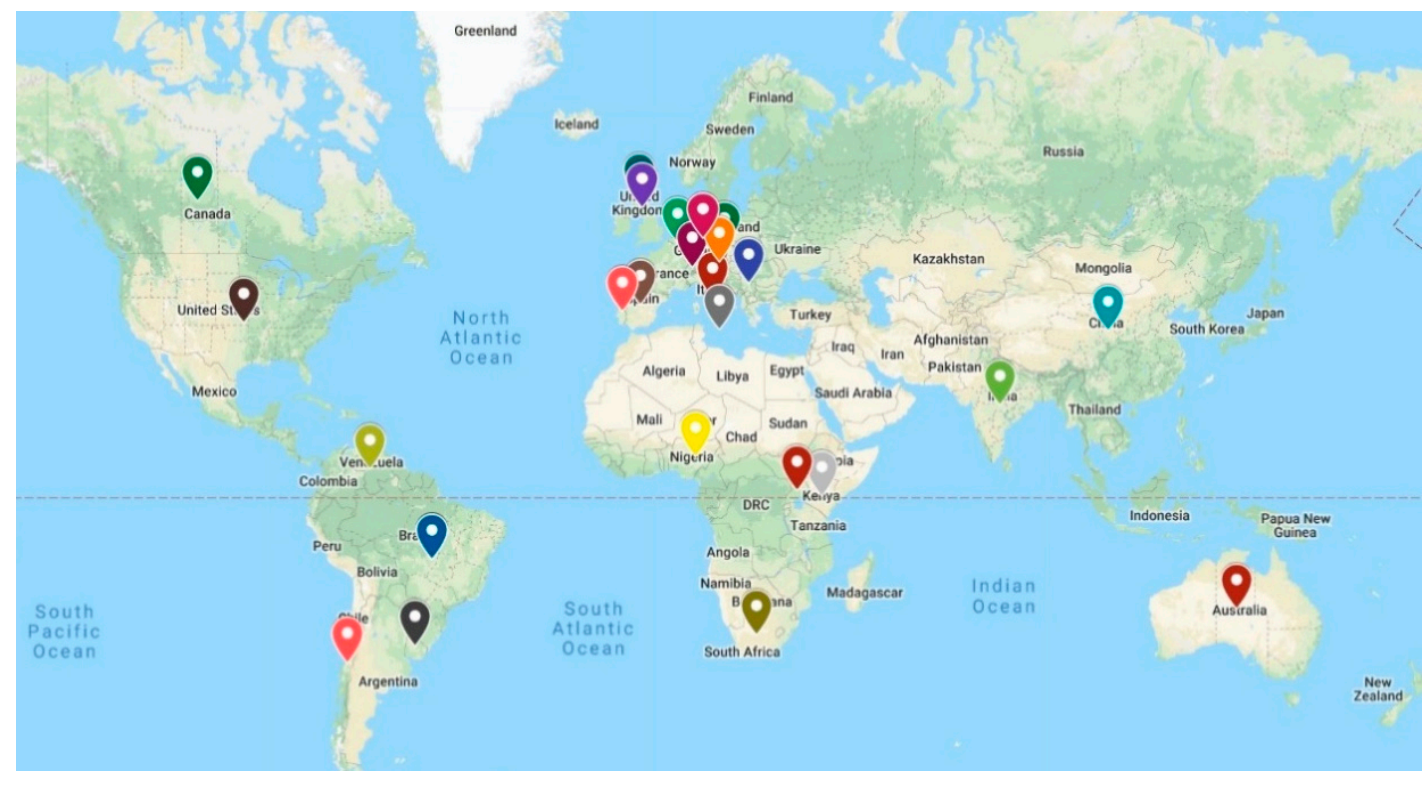

Figure 1. Countries from which questionnaires were returned.

The survey represents a broad sample of professional practice and options from the global university sector. Regarding occupation, most part of the respondents are lecturers or professors at the universities $(48 \%)$, followed by administrative staff $(31 \%)$. At lower rates there are researchers $(13 \%)$ and students $(8 \%)$.

Statistical analyses were performed on the data collected with the Statistical Package for the Social Sciences-SPSS [41]. The following analyses were performed through the software: Simple descriptive statistics for presenting the results of each statement; transformation of the Likert Scale to number a common scale as follows: (1) Strongly disagree, (2) Disagree, (3) Do not know, (4) Agree, and (5) Strongly agree, which enabled the use of mean to discuss differences between regions and occupation of the respondents; and finally the use of the Kruskal-Wallis $\mathrm{H}$ test, in order to assess significant differences among the geographical regions when it comes to climate action in their universities. 


\section{Results and Discussion}

This section is divided into two parts. The first one presents a description of the personal beliefs of the respondents on climate change and the descriptive statistical analysis for each statement. The second part consists of the analysis of the association between socio-demographic factors (region and occupation) and the gathered results. Due to the fact that many questions and answers are inter-related they are also discussed, and their implications are duly analysed.

\subsection{Personal Beliefs and Perceptions of Climate Change at Universities}

Along with the questions regarding country and occupation, the respondents were given three sentences concerning climate change and were asked to state which one they believe in. Table 2 shows that an overwhelming majority $(96.6 \%)$ believe that climate change is happening now and that human activities are the main cause of it. A great part of the sample is among those who acknowledge the impacts of climate change and the human responsibility, not being connected to the group of people who question or doubt that $[33,34,38]$.

Table 2. Personal beliefs of participants.

\begin{tabular}{ccc}
\hline Option & $\boldsymbol{n}$ & $\mathbf{\%}$ \\
\hline Climate change is happening now, caused mainly by human activities & 229 & 96.6 \\
Climate change is happening now but caused mainly by natural forces & 4 & 1.7 \\
Climate change is not happening now & 1 & $\mathbf{0 . 4}$ \\
Don't know/no answer & $\mathbf{3}$ & $\mathbf{1 . 2}$ \\
\hline Total & 237 & 100.0 \\
\hline
\end{tabular}

The main part of the survey included 14 separate statements which required the participants to select one option from a five-point Likert scale according to their preferences. Table 3 presents the results obtained.

The questionnaire included one general statement about climate change perception (S1), six statements regarding the role that universities should perform in climate action (S2-S7) and seven statements more focused on the actual university policies and procedures in the respondent's university (S8-S14).

In the statements of general nature and role of universities (S1-S7) the scores were very positive indicating that the participants agreed or strongly agreed with these statements. The statement which got the highest 'strongly agree' score was S5, concerning education about the causes of climate change $(81.9 \%)$, and the lowest score $(63.3 \%)$ was achieved by S6, which entails the contribution through operations to achieve the adaptation strategies to climate change set by the government.

Generally, the participants exhibited positive perceptions on the role of universities about climate change. On the other hand, when asked about actual policies and procedures being carried out at the participants' universities (S8-S10), the majority of responses exhibit a substantial drop from the results of the first seven questions. Only two of the statements have a strongly-agree score that exceeds $10 \%$, which are S8 and S14, focused on attaching importance to climate change (11.8\%) and addressing climate change through Education for Sustainable Development (16.5\%). If all positive responses are computed (Agree and Strongly Agree), both statements are 59.1\% and 57.9\%. All the other statements have a 'strongly agree' score of less than $10 \%$, indicating a gap between the perception of "what universities should do" and "what universities are really doing."

Another recent online-survey paper on climate change at Higher Education Institutions (HEIs) found that only $30 \%$ of participating universities have a policy or plan for the capacity building of teachers in climate change teaching and research. The lack of funds is identified as the primary barrier to climate change research (CCR), although the complex, uncertain and interdisciplinary nature of CCR also challenges HEIs [42]. For instance, interdisciplinary projects can struggle to attract support 
research because expert peer-reviewers are generally senior academics that have highly specialised expertise $[42,43]$.

Table 3. Perceptions of climate change issues by the respondents (in \%).

\begin{tabular}{|c|c|c|c|c|c|c|}
\hline & Statement & Strongly Disagree & Disagree & Don't know & Agree & Strongly Agree \\
\hline \multirow{7}{*}{ 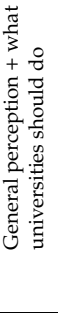 } & S1. The consequences of climate change will be very serious. & 3.4 & 0.4 & 1.7 & 17.3 & 76.8 \\
\hline & S2. A university should have a climate change policy. & 3.0 & 3.0 & 5.1 & 21.9 & 67.1 \\
\hline & $\begin{array}{l}\text { S3. A university should contribute in its operation to achieve the } \\
\text { carbon reduction targets set by the government. }\end{array}$ & 0.8 & 0.8 & 2.5 & 28.3 & 67.5 \\
\hline & $\begin{array}{l}\text { S4. A university should contribute in its operation to achieve the } \\
\text { adaptation strategies to climate change set by the government. }\end{array}$ & 0.8 & 0.4 & 5.5 & 30.0 & 62.4 \\
\hline & $\begin{array}{l}\text { S5. A university should educate its students about the cause of } \\
\text { climate change. }\end{array}$ & 0.8 & 0.0 & 0.4 & 15.6 & 81.9 \\
\hline & $\begin{array}{l}\text { S6. A university should educate its students about the impact of } \\
\text { climate change in all disciplines. }\end{array}$ & 0.8 & 4.6 & 4.2 & 25.7 & 63.3 \\
\hline & $\begin{array}{l}\text { S7. A university should encourage its students to search for } \\
\text { solutions with regards to problems caused by climate change. }\end{array}$ & 0.4 & 0.8 & 2.1 & 22.8 & 73.0 \\
\hline \multirow{7}{*}{ 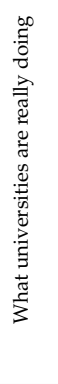 } & $\begin{array}{l}\text { S8. Your University attaches a lot of importance to matters related to } \\
\text { climate change. }\end{array}$ & 5.9 & 22.4 & 11.4 & 47.3 & 11.8 \\
\hline & $\begin{array}{l}\text { S9. The official policy or planning framework for combating climate } \\
\text { change at your University is well developed. }\end{array}$ & 11.8 & 34.6 & 22.4 & 25.7 & 4.6 \\
\hline & $\begin{array}{l}\text { S10. The person in charge of planning on matters related to climate } \\
\text { change issues at your university is afforded enough resources to } \\
\text { work effectively. }\end{array}$ & 17.7 & 27.8 & 36.3 & 14.3 & 3.0 \\
\hline & $\begin{array}{l}\text { S11. Climate change policies, procedures or activities are properly } \\
\text { implemented in teaching and research at your University. }\end{array}$ & 9.7 & 38.8 & 21.9 & 25.7 & 2.5 \\
\hline & $\begin{array}{l}\text { S12. My university contributes in its operation to achieve the carbon } \\
\text { reduction targets set by the government. }\end{array}$ & 7.2 & 22.8 & 21.1 & 38.4 & 9.7 \\
\hline & $\begin{array}{l}\text { S13. My university educates its students about the impact of climate } \\
\text { change on the discipline chosen by the student. }\end{array}$ & 5.5 & 27.4 & 23.6 & 35.9 & 5.1 \\
\hline & $\begin{array}{l}\text { S14. There are specific units that address climate change through } \\
\text { 'Education for Sustainable Development' at my University. }\end{array}$ & 5.5 & 19.0 & 16.9 & 41.4 & 16.5 \\
\hline
\end{tabular}

\subsection{Further Statistical Analysis}

This section of the quantitative data analysis section presents the results obtained from further descriptive analysis with the data. After assigning numbers from one to five for each category label of the Likert Scale, the means obtained from each statement were grouped and compared to each other in order to identify any tendencies in the data. This method was mainly used to compare the two socio-demographic indicators of the questionnaire respondents (region and occupation), and their answers to each statement. The results indicate that there were no visible tendencies when the socio-demographic indicator was occupation (Table 4). However, some visible tendencies were found when the socio-demographic indicator was 'region' (Table 5). The means of both South America and of Asia are continuously ranked in the lowest two categories for the majority of the statements.

Table 4. Occupation of respondents.

\begin{tabular}{cccccc}
\hline Question & Lecturer/Professor & Researcher & Student & Administrative Staff & All \\
\hline S1 & 4.60 & 4.77 & 4.55 & 4.68 & 4.64 \\
S2 & 4.42 & 4.48 & 4.55 & 4.52 & 4.47 \\
S3 & 4.55 & 4.58 & 4.80 & 4.63 & 4.60 \\
S4 & 4.51 & 4.58 & 4.68 & 4.53 & 4.54 \\
S5 & 4.79 & 4.83 & 4.84 & 4.78 & 4.79 \\
S6 & 4.43 & 4.41 & 4.25 & 4.66 & 4.47 \\
S7 & 4.63 & 4.70 & 4.75 & 4.74 & 4.68 \\
S8 & 3.34 & 3.23 & 3.25 & 3.50 & 3.37 \\
S9 & 2.65 & 2.53 & 2.60 & 3.05 & 2.76 \\
S10 & 2.52 & 2.50 & 2.35 & 2.74 & 2.56 \\
S11 & 2.64 & 2.50 & 2.95 & 2.88 & 2.72 \\
S12 & 3.04 & 3.20 & 2.90 & 3.56 & 3.20 \\
S13 & 2.95 & 3.24 & 3.15 & 3.15 & 3.07 \\
S14 & 3.42 & 3.36 & 3.36 & 3.52 & 3.44 \\
\hline
\end{tabular}

Lowest scores $(<3.00)$ highlighted in grey-Scores are the averages of the five-point Likert Scale raw data. Range is 1-5. 
Table 5. Mean for each statement as grouped by region *.

\begin{tabular}{cccccccc}
\hline Question & Europe & Asia & S. America & N. America & Oceania & Africa & All Regions \\
\hline S1 & 4.70 & 4.33 & 4.52 & 4.73 & 4.66 & 4.60 & 4.64 \\
S2 & 4.61 & 4.50 & 4.06 & 4.63 & 4.25 & 4.47 & 4.47 \\
S3 & 4.80 & 4.33 & 4.45 & 4.47 & 4.58 & 4.47 & 4.60 \\
S4 & 4.66 & 4.25 & 4.39 & 4.45 & 4.72 & 4.56 & 4.54 \\
S5 & 4.79 & 5.00 & 4.70 & 4.92 & 4.83 & 4.68 & 4.79 \\
S6 & 4.50 & 4.81 & 4.20 & 4.44 & 4.50 & 4.69 & 4.47 \\
S7 & 4.65 & 4.66 & 4.62 & 4.73 & 5.00 & 4.65 & 4.68 \\
S8 & 3.59 & 2.83 & 2.85 & 3.81 & 3.25 & 3.00 & 3.37 \\
S9 & 2.90 & 2.58 & 2.22 & 3.26 & 2.91 & 2.27 & 2.76 \\
S10 & 2.77 & 2.33 & 2.22 & 2.73 & 2.41 & 2.22 & 2.56 \\
S11 & 2.80 & 2.36 & 2.50 & 3.02 & 2.83 & 2.54 & 2.72 \\
S12 & 3.51 & 2.58 & 2.56 & 3.68 & 3.41 & 2.68 & 3.20 \\
S13 & 3.15 & 3.33 & 2.93 & 3.15 & 2.72 & 2.76 & 3.07 \\
S14 & 3.59 & 2.75 & 3.04 & 3.68 & 3.83 & 3.31 & 3.44 \\
\hline
\end{tabular}

* Lowest scores $(<3.00)$ highlighted in grey-Scores are the averages of the five-point Likert Scale raw data. Range is $1-5$.

The results indicate that perceptions of climate change by university staff appear to be more dependent on region rather than occupation. Europe, North America and Australia obtain the highest 'agreement' scores in most statements while the lowest are Asia, South America and Africa, with the latter performing marginally better than the other two.

The results also indicate the presence of a 'gap' between the mean results of the first seven statements which ask generic questions about university roles and the second set of seven questions which are specific to the particular reality of the universities. This trend is visible in all the regions and is not only specific to a particular one. The same applies to the means obtained regarding occupation of the respondents. It confirms the worldwide gap between what universities should be doing and what they are actually doing.

Finally, Table 6 presents the results obtained from the Kruskal-Wallis test, concerning significant correlations. This non-parametric test was used to compare the two socio-demographic indicators of the questionnaire respondents (region and occupation), and their answers to each statement. The results indicate that there were no significant correlations when the socio-demographic indicator was occupation. However, a number of significant results were found when the socio-demographic indicator was 'region'.

Table 6. Selection of significant correlations obtained from the Kruskal-Wallis test.

\begin{tabular}{|c|c|c|c|}
\hline Statement & Social Indicator & $p$-Value & Mean \\
\hline S2 A university should have a climate change policy. & Region & $p=0.026$ & $\begin{array}{l}\text { South America has } \\
\text { lowest score }\end{array}$ \\
\hline $\begin{array}{l}\text { S3 A university should contribute in its operation to achieve } \\
\text { the carbon reduction targets set by the government. }\end{array}$ & Region & $p=0.002$ & Asia has lowest score \\
\hline $\begin{array}{l}\text { S4 A university should contribute in its operation to achieve } \\
\text { the adaptation strategies to climate change set by the } \\
\text { government. }\end{array}$ & Region & $p=0.045$ & Asia has lowest score \\
\hline $\begin{array}{l}\text { S8 Your University attaches a lot of importance to matters } \\
\text { related to climate change. }\end{array}$ & Region & $p=0.000$ & $\begin{array}{l}\text { Asia, South America and } \\
\text { Africa have lowest scores }\end{array}$ \\
\hline $\begin{array}{l}\text { S9 The official policy or planning framework for combating } \\
\text { climate change at your University is well developed. }\end{array}$ & Region & $p=0.000$ & $\begin{array}{l}\text { South America and Africa } \\
\text { have lowest scores }\end{array}$ \\
\hline $\begin{array}{l}\text { S10 The person in charge of planning on matters related to } \\
\text { climate change issues at your University is afforded enough } \\
\text { resources to work effectively. }\end{array}$ & Region & $p=0.013$ & $\begin{array}{l}\text { South America and Africa } \\
\text { have lowest scores }\end{array}$ \\
\hline $\begin{array}{l}\text { S12 My University contributes in its operation to achieve the } \\
\text { carbon reduction targets set by the government. }\end{array}$ & Region & $p=0.000$ & $\begin{array}{l}\text { Asia, South America and } \\
\text { Africa have lowest scores }\end{array}$ \\
\hline $\begin{array}{l}\text { S14 There are specific units that address climate change } \\
\text { through 'Education for Sustainable Development' } \\
\text { at my University }\end{array}$ & Region & $p=0.007$ & $\begin{array}{c}\text { Asia and South America have } \\
\text { lowest scores }\end{array}$ \\
\hline
\end{tabular}


The results indicate that perceptions on climate change by universities are more dependent on region rather than occupation. The correlations indicate statistical significance between a number of statements and the region from which the University originates. The highest 'agreement' scores in these eight statements were obtained by Europe, North America and Australia while the lowest ones are from Asia, South America and Africa, with the latter performing marginally better than the other two. More specifically results indicate that:

1. South American universities are the ones which least believe that universities should have a climate change policy;

2. Asian universities are least likely to believe that a university should contribute in its operation to achieve the carbon reduction targets and adaptation strategies set by the government;

3. Asian, South American and African universities attach less importance to matters related to climate change and contribute less in their operation to achieve the carbon reduction targets set by the government, when compared to other regions (Europe, North America, Asia and Oceania);

4. South American and African Universities have a less developed official policy or planning framework for combating climate change, and have the least specific units that address climate change through 'Education for Sustainable Development' when compared to other regions.

As suggested by Leal Filho et al. [44] a mix of development status levels, concerns, priorities, lack of formal structures and lack of funds or how resources are allocated can explain the difficulties in connecting sustainability and climate action in HEIs [45], and could also explain the differences observed in this paper. For Molthan-Hill et al. [46] universities from different countries focus on climate change education in several ways, being difficult to identify clear patterns of action-which confirms the wide range of ideas and approaches being used to date when it comes to climate change.

The above findings are to some extent consistent with the literature on climate change scepticism, corroborating Senbel, Ngo and Blair's [9] views that social mobilisation is needed in order to foster a greater engagement on climate issues. The uncertainties related to climate change, as explored by Whitmarsh [25] should not however be a reason for no action. Whereas some progress has been seen over the past years in respect of public perceptions of climate change [27] views on the harms should not overlook the fact that each individual—within a university and outside it-may play a role in the process, especially in more affluent societies.

\section{Conclusions}

It is understood that universities occupy a central position as centres of learning, innovation and research. Consistent with these multiple roles, there are many ways via which universities can engage on matters related to climate change. Apart from deep actions such as the execution of research projects which may investigate matters related to climate change mitigation and adaptation, university engagement on climate issues can be as simply as institutional climate protection, i.e., fostering energy efficiency by investing in low-cost and energy saving equipment, devices and lights, or by the use of renewable energy sources in order to reduce their $\mathrm{CO}_{2}$ emissions. Efforts can also be more intensive and have a multiplier role, such as the inclusion of climate issues in the curriculum, making it more present and more visible in university programmes. However, in order that this is achieved, there is a perceived need to address the currently seen scepticism, since a reluctance to engage on climate issues means that good opportunities to educate and raise awareness about them are being lost.

This paper has demonstrated that across the world, many efforts are being made in order to make climate change issues more present in university programmes and initiatives. To the same measure, it has identified the fact that some developments offer reasons for concern, such as the fact that there seems no consensus about the real value of climate change policies (which universities in Asia showed the lowest scores) or that an institutional framework to handle climate change had so few Latin American and African responses. 
One means to reduce scepticism and perhaps consolidate institutional efforts is by means of a greater involvement of university students on climate matters: such an engagement-via teaching, research or extra-mural activities - may lead to a greater interest and better preparation of our future professionals, to handle the causes and roots of climate change and in finding innovative ways via which we can adapt to a changing climate. There are various opportunities to tackle climate issues as part of teaching programmes, and more use should be made of the many chances they provide, and via which the levels of climate change scepticism at universities may be inter alia reduced.

All these opportunities tend to contribute also to reduce the gap observed in this paper, concerning the differences between "what universities should do" and "what universities are really doing," especially in developing countries.

The novelty of the work here reported resides on the fact that it offers an overview of the emphasis currently being given to climate issues among universities, and points out some of the deficiencies seen, and which need to be addressed.

The policy implications of this paper are threefold: firstly, it shows that universities are yet to fully incorporate climate related issues as part of their programmes, a trend that suggests that more efforts in respect of policy-making are needed, to encourage them to take climate matters more into account when training future professionals. Secondly, a combined approach to both science, policy and teaching is needed, so as to make students more knowledgeable about matters related to climate change, and encourage them to take more responsibility for climate related matters in their future professions. Finally, since decisions are not necessarily made based on facts, but on what people perceive as right or wrong, it is important that policy-making on climate change and which may be of relevance to universities, addresses issues related to vulnerability, especially among poor communities, since these suffer the most from the many climate change impacts.

The limitations of this study include the sample used and the possible bias based on who the respondents were. Further research is needed in respect of how and why regional differences found herein, affects education for sustainable development (including climate change) and climate change research in HEIs in the studied regions, the difference between climate change adaptation and mitigation, and how they relate to sustainable development in developed and developing countries.

Author Contributions: As described in the digital form of the journal online. All of the authors approved the publication.

Funding: This research did not receive external funding.

Conflicts of Interest: Authors declare no conflict of interest.

\section{Appendix A}

A. University Location

B. Professional role at University

C. Which of the following three statements do you personally believe?

( ) Climate change is happening now, caused mainly by human activities.

() Climate change is happening now, but caused mainly by natural forces.

( ) Climate change is not happening now

( ) Don't know/no answer

1. The consequences of climate change will be very serious.

( ) Strongly disagree ( ) Disagree ( ) Don't know ( ) Agree ( ) Strongly agree

2. A university should have a climate change policy.

( ) Strongly disagree ( ) Disagree ( ) Don't know ( ) Agree ( ) Strongly agree 
3. A university should contribute in its operation to achieve the carbon reduction targets set by the government.

( ) Strongly disagree ( ) Disagree ( ) Don't know ( ) Agree ( ) Strongly agree

4. A university should contribute in its operation to achieve the adaptation strategies to climate change set by the government.

( ) Strongly disagree ( ) Disagree ( ) Don't know ( ) Agree ( ) Strongly agree

5. A university should educate its students about the cause of climate change.

( ) Strongly disagree ( ) Disagree ( ) Don't know ( ) Agree ( ) Strongly agree

6. A university should educate its students about the impact of climate change in all disciplines.

( ) Strongly disagree ( ) Disagree ( ) Don't know ( ) Agree ( ) Strongly agree

7. A university should encourage its students to search for solutions with regards to problems caused by climate change.

( ) Strongly disagree ( ) Disagree ( ) Don't know ( ) Agree ( ) Strongly agree

8. Your University attaches a lot of importance to matters related to climate change. $\mathrm{w}$

( ) Strongly disagree ( ) Disagree ( ) Don't know ( ) Agree ( ) Strongly agree

9. The official policy or planning framework for combating climate change at your University is well developed.

( ) Strongly disagree ( ) Disagree ( ) Don't know ( ) Agree ( ) Strongly agree

10. The person in charge of planning on matters related to climate change issues at your university is afforded enough resources to work effectively.

( ) Strongly disagree ( ) Disagree ( ) Don't know ( ) Agree ( ) Strongly agree

11. Climate change policies, procedures or activities are properly implemented in teaching and research at your University.

( ) Strongly disagree ( ) Disagree ( ) Don't know ( ) Agree ( ) Strongly agree

12. My university contributes in its operation to achieve the carbon reduction targets set by the government.

( ) Strongly disagree ( ) Disagree ( ) Don't know ( ) Agree ( ) Strongly agree

13. My university educates its students about the impact of climate change on the discipline chosen by the student.

( ) Strongly disagree ( ) Disagree ( ) Don't know ( ) Agree ( ) Strongly agree

14. There are specific units that address climate change through 'Education for Sustainable Development' at my University.

( ) Strongly disagree ( ) Disagree ( ) Don't know ( ) Agree ( ) Strongly agree

\section{References}

1. Suwartha, N.; Sari, R.F. Evaluating UI GreenMetric as a tool to support green universities development: Assessment of the year 2011 ranking. J. Clean. Prod. 2013, 61, 46-53. [CrossRef]

2. Salvia, A.L.; Leal, F.W.; Brandli, L.L.; Griebeler, J.S. Assessing research trends related to Sustainable Development Goals: Local and global issues. J. Clean. Prod. 2019, 208, 841-849. [CrossRef]

3. Vejrostová, L.; Lisá, L.; Bajer, A.; Pacina, J. Evaluation of human impact on valley bottom sedimentation in Highlands: Case study from Ceská Bělá, Czechia. Geografie 2017, 122, 21-44.

4. Leal, F.W. Communicating climate change: Challenges ahead and action needed. Int. J. Climate Change Strateg. Manag. 2009, 1, 6-18. [CrossRef]

5. Leal, F.W.; Manolas, E.; Azul, A.M.; Azeiteiro, U.M.; McGhie, H. (Eds.) Handbook of Climate Change Communication: Theory of Climate Change Communication; Springer: Berlin, Germany, 2018; Volume 1. 
6. Geng, Y.; Liu, K.; Xue, B.; Fujita, T. Creating a "green university" in China: A case of Shenyang University. J. Clean. Prod. 2013, 61, 13-19. [CrossRef]

7. Dyer, G.; Dyer, M. Strategic leadership for sustainability by higher education: the American College and University Presidents' Climate Commitment. J. Clean. Prod. 2017, 140, 111-116. [CrossRef]

8. The White House President Barack Obama, Office of the Press Secretary. American Campuses Act on Climate. 2015. Available online: https://obamawhitehouse.archives.gov/the-press-office/2015/12/11/ american-campuses-act-climate (accessed on 23 September 2017).

9. Senbel, M.; Ngo, V.D.; Blair, E. Social mobilization of climate change: University students conserving energy through multiple pathways for peer engagement. J. Environ. Psychol. 2014, 38, 84-93. [CrossRef]

10. Campus Conservation Nationals (CNN). CCN is the Biggest Short-Term Energy Reduction Competition in History. 2016. Available online: http://ccn.lucidconnects.com/overview-1/ (accessed on 23 September 2017).

11. Cornell University. Cornell Climate Change. 2017. Available online: http://climatechange.cornell.edu/about/ (accessed on 23 September 2017).

12. University and College Presidents' Climate Change Statement of Action for Canada. 2017. Available online: http://www.climatechangeaction.ca/ (accessed on 23 September 2017).

13. University of Winchester. Climate Change Education at the University of Winchester-A Five Year Strategy 2016-2021. 2016. Available online: http:/www.winchester.ac.uk/Freedomofinformation/Publicdocuments/ PublicDocuments/Climate\%20Change\%20Education\%20Strategy.pdf (accessed on 23 September 2017).

14. EAUC. Universities and Colleges Climate Commitment for Scotland. 2017. Available online: http: //www.eauc.org.uk/universities_and_colleges_climate_commitment_fo2 (accessed on 23 September 2017).

15. ICCIRP. The International Climate Change Information and Research Programme. HAW Hamburg. 2019. Available online: https://www.haw-hamburg.de/en/ftz-nk/programmes/iccirp.html (accessed on 8 April 2019).

16. Padgham, J.; Virji, H.; Seipt, C. Promoting climate change curricula development in African universities. Environ. Dev. 2013, 5, 169-171. [CrossRef]

17. SARUA. African Universities Take the Lead in Climate Change. 2017. Available online: http://www.sarua. org/?q=content/african-universities-take-lead-climate-change (accessed on 23 September 2017).

18. Worldwide Universities Network. Changing Coasts, Climate Change and Other Drivers. 2017. Available online: https://wun.ac.uk/wun/research/view/changing-coasts-climate-change-and-other-drivers (accessed on 23 September 2017).

19. Kolstad, C.; Urama, K.; Broome, J.; Bruvoll, A.; Olvera, M.C.; Fullerton, D.; Gollier, C.; Hanemann, W.M.; Hassan, R.; Jotzo, F.; et al. Social, economic and ethical concepts and methods. In Climate Change 2014: Mitigation of Climate Change. Contribution of Working Group III to the Fifth Assessment Report of the Intergovernmental Panel on Climate Change; Edenhofer, O., Pichs-Madruga, R.Y., Sokona, E., Farahani, S., Kadner, K., Seyboth, A., Adler, I., Baum, S., Brunner, P., et al., Eds.; Cambridge University Press: Cambridge, UK, 2014.

20. Claesson, J.; Nycander, J. Combined effect of global warming and increased $\mathrm{CO}_{2}$ - concentrations on vegetation growth in water-limited conditions. Ecol. Modell. 2013, 256, 23-30. [CrossRef]

21. Rotton, J.; Cohn, E. Global warming and U.S. crime rates: An application of routine activity theory. Environ. Behav. 2003, 35, 802-825. [CrossRef]

22. Nordås, R.; Gleditsch, N.P. Climate change and conflict. Political Geogr. 2007, 26, 627-638. [CrossRef]

23. Li, C.; Song, Y. Government response to climate change in China: A study of provincial and municipal plans. J. Environ. Plan. Manag. 2016, 59, 1679-1710. [CrossRef]

24. Li, C. Essays on Climate Change Mitigation, Building Energy Efficiency, and Urban Form. Ph.D. Thesis, The University of North Carolina, Chapel Hill, NC, USA, 2018.

25. Whitmarsh, L. Scepticism and uncertainty about climate change: Dimensions, determinants and change over time. Global Environ. Change 2011, 21, 690-700. [CrossRef]

26. Pidgeon, N. Public understanding of, and attitudes to, climate change: UK and international perspectives and policy. Climate Policy 2012, 12 (Suppl. 1), S85-S106. [CrossRef]

27. Capstick, S.; Whitmarsh, L.; Poortinga, W.; Pidgeon, N.; Upham, P. International trends in public perceptions of climate change over the past quarter century. Wiley Interdisc. Rev. Climate Change 2015, 6, 35-61. [CrossRef] 
28. Peyton, R.B.; Miller, B.A. Developing an internal locus of control as a prerequisite to environmental action taking. In Current Issues VI: The Yearbook of Environmental Education and Environmental Studies; Sacks, A.B., Ed.; Clearinghouse for Science, Mathematics, and Environmental Education: Columbus, OH, USA, 1980; pp. 173-192.

29. Hines, J.M.; Hungerford, H.R.; Tomera, A.N. Analysis and synthesis of research on responsible environmental behaviour: A meta-analysis. J. Environ. Educ. 1986, 18, 1-8. [CrossRef]

30. Kellstedt, P.; Zahran, S.; Vedlitz, A. Personal efficacy, the information environment, and attitudes towards global warming and climate change in the United States. Risk Anal. 2008, 28, 113-126. [CrossRef] [PubMed]

31. Mostafa, M. Post-materialism, religiosity, political orientation, locus of control and concern for global warming: A multilevel analysis across 40 nations. Soc. Indic. Res. 2016, 128, 1273-1298. [CrossRef]

32. Van Rensburg, W. Climate change scepticism: A conceptual re-evaluation. Sage Open J. 2015, 5, 2158244015579723. [CrossRef]

33. Capstick, S.B.; Pidgeon, N.F. What is climate change scepticism? Examination of the concept using a mixed methods study of the UK public. Global Environ. Change 2014, 24, 389-401. [CrossRef]

34. Pickering, G.J. Barriers to Change: Climate Change Scepticism and Uncertainty in Canada. Environmental Sustainability Research Centre (ESRC), 2016. Available online: http://dr.library.brocku. ca/bitstream/handle/10464/9459/Working\%20Paper\%20-\%20ESRC-2016-001.pdf?sequence=1 (accessed on 5 April 2019).

35. Akter, S.; Bennett, J.; Ward, M.B. Climate change scepticism and public support for mitigation: Evidence from an Australian choice experiment. Global Environ. Change 2012, 22, 736-745. [CrossRef]

36. Whitmarsh, L. What's in a name? Commonalities and differences in public understanding of 'climate change' and 'global warming'. Public Underst. Sci. 2009, 18, 401-420. [CrossRef]

37. McCrea, R.; Leviston, Z.; Walker, I.A. Climate change skepticism and voting behavior: What causes what? Environ. Behav. 2015, 48, 1309-1334. [CrossRef]

38. Hornsey, M.J.; Harris, E.; Bain, P.G.; Fielding, K.S. Meta-analyses of the determinants and outcomes of belief in climate change. Nat. Clim. Change 2016, 6, 622. [CrossRef]

39. Björnberg, K.E.; Karlsson, M.; Gilek, M.; Hansson, S.E. Climate and environmental science denial: A review of the scientific literature published in 1990-2015. J. Clean. Prod. 2017, 167, 229-241. [CrossRef]

40. IUSDRP. Inter-University Sustainable Development Research Programme. 2019. Available online: https: //www.haw-hamburg.de/en/ftz-nk/programmes/iusdrp.html (accessed on 8 April 2019).

41. SPSS. SPSS 16.0 Command Syntax Reference; SPSS Inc.: Chicago, IL, USA, 2007; Available online: https://www.uni-muenster.de/imperia/md/content/ziv/service/software/spss/handbuecher/englisch/spss_ 16.0_command_syntax_reference.pdf (accessed on 8 April 2019).

42. Leal, F.W.; Morgan, E.A.; Godoy, E.S.; Azeiteiro, U.M.; Bacelar-Nicolau, P.; Veiga Ávila, L.; Mac-Lean, C.; Hugé, J. Implementing climate change research at universities: Barriers, potential and actions. J. Clean. Prod. 2018, 170, 269-277. [CrossRef]

43. Holm, P.; Goodsite, M.E.; Cloetingh, S.; Agnoletti, M.; Moldan, B.; Lang, D.J.; Leemans, R.; Moeller, J.O.; Buendía, M.P.; Pohl, W.; et al. Collaboration between the natural, social and human sciences in Global Change Research. Environ. Sci. Policy 2013, 28, 25-35. [CrossRef]

44. Leal, F.W.; Azeiteiro, U.M.; Alves, F.; Pace, P.; Mifsud, M.; Brandli, L.; Caeiro, S.S.; Disterheft, A. Reinvigorating the sustainable development research agenda: The role of the sustainable development goals (SDG). Int. J. Sustain. Dev. World Ecol. 2017, 25, 131-142. [CrossRef]

45. Leal, F.W.; Chun, Y.; Wu, J.; Brandli, L.L.; Veiga Avila, L.; Azeiteiro, U.M.; Caeiro, S.S.; Gama Madruga, L.R. Identifying and overcoming obstacles to the implementation of sustainable development at universities. J. Integr. Environ. Sci. 2017, 14, 93-108. [CrossRef]

46. Molthan-Hill, P.; Worsfold, N.; Nagy, G.J.; Leal, F.W.; Mifsud, M. Climate change education for universities: A conceptual framework from an international study. J. Clean. Prod. 2019, 226, 1092-1101. [CrossRef]

(C) 2019 by the authors. Licensee MDPI, Basel, Switzerland. This article is an open access article distributed under the terms and conditions of the Creative Commons Attribution (CC BY) license (http://creativecommons.org/licenses/by/4.0/). 